\title{
Toward a Pentecostal Understanding of Communio Sanctorum: Reflections on Peter Kuzmič \& Miroslav Volf's "Theology of the Church as a Fellowship of Persons" in the Context of the Pentecostal-Roman Catholic Dialogue
}

\section{Ciprian Gheorghe-Luca}

Faculty of Humanities and Social Sciences of the 'Aurel Vlaicu' University of Arad, Romania ciprian.luca@uav.ro

\begin{abstract}
The purpose of this paper is to reflect on the Pentecostal understanding of the communion of saints by critically engaging with the ecclesiological vision of two world-class Pentecostal theologians from post-communist countries: Peter Kuzmič and Miroslav Volf. The paper has three sections: in the first one, a brief historical and theological overview of the doctrine of communio sanctorum is presented, to both set the stage for the core of the paper, and to point out the usefulness of reflecting on this particular ecclesiological topic. The second section offers an outline of "Perspectives on Koinonia" (the final report from the Third Quinquennium of the Pentecostal-Roman Catholic Dialogue), focusing on the first round of talks (Riano, Italy, 1985), which were on the topic of communio sanctorum. In the third section, the author presents and engages with Kuzmič \& Volf's paper, "Theology of the Church
\end{abstract}


as a Fellowship of Persons" which represents one of the earliest attempts to articulate a Pentecostal ecclesiology based on the notion of communio sanctorum. In the end, the author will attempt to show how this ecclesiological vision helps the shaping of a Pentecostal theology of public life.

Keywords: communio sanctorum, Pentecostalism, ecclesiology, communion of saints, ecumenical dialogue, theology of public life

\section{A Brief Historical and Theological Overview of Communio Sanctorum}

Historically speaking, it may come as a surprise that the phrase "communion of saints" is a late arrival into "the most universally accepted creed in Western Christendom" (Pelikan 2005, 187). Strangely enough, although it most likely came from Byzantium (the Greek koinonia ton hagion is the equivalent of the Latin communio sanctorum), the term does not appear either in the Niceno-Constantinopolitan Creed or in the Old Roman Creed. Its first attested appearance is in the Creed of Niceta (c. 370-414 A.D.; see Burn 1905, lxxx) in Remensiana (present-day Bela Palanka, in modern Serbia, which was the main road between Western Europe and Constantinople - the "new Rome" at that time). It also appeared in the Creed of Jerome (c. 342-420 A.D.). In the sixth century, it became a profession of faith in the Galician Creed. It was only towards the end of the eighth century when it was introduced universally by Rome in the Apostles' Creed.

Theologically speaking, scholarly opinions on the meaning of the phrase are divided. Some scholars have argued that the "communion of saints" has never been a precise doctrine, that it has favored many interpretations, continuing to be ambivalent for many believers (Carson and Cerrito 2003,34), and that it has been so much neglected as to deserve being described as a "sleeping symbol" (Johnson 1998, 9; Imbelli 1998, 24-5). William Barclay, Charles Heurtley, and J. N. D. Kelly agree that the meaning of communio sanctorum has fluctuated in the history of the Church. Barclay, for example, argues that the phrase has a vague meaning, because of the hermeneutical and dogmatic difficulties which make it more of a technical church term (Barclay 1967, 291), while Heurtley $(1858,146)$ and Kelly (1981, 389-97), well-known for their pioneer and ample work on the early Christian creeds, have noted that different perspectives had been expressed on the significance of the phrase, as it first lacked the certitude of the other articles in the Apostles' Creed. Yet other, more recent scholarly voices, like Leonard DeLorenzo of Notre Dame University, have sought to make a case for the sacramental and mystical (all-saints) meaning, emphasizing that "the "communion of saints" is a definitive mark of the Christian imagination conformed to the mystery of salva- 
tion" (DeLorenzo 2017, 7). ${ }^{1}$ Not surprisingly, most Evangelical Christians, who generally have a "free church" ecclesiology, disregard any (possible) sacramental significance, in favor of a more socially oriented understanding of the fellowship.

It can be easily noticed that two Latin terms give shape to the concept: 1) communio (from the Greek term koinonia), which means fellowship or communion in English, and 2) sanctorum (from the Greek term hagios), which means the holy/the saints and can point to either sancta (holy things) or sancti (holy persons).

While there are no ample theological disagreements between Roman-Catholics and Evangelicals (including Pentecostals) on the implications of the term communio itself - both sides agree that fellowship is biblical and vital for the Church - the meaning of the whole phrase communio sanctorum or sanctorum communionem (as used sometimes) is problematic and, therefore, debatable. What did fourth or eighth-century Christians have in mind when they used this phrase as a profession of their faith about the Church? Were they referring to the fellowship of the "holy things" (the sacraments of which they partook) or to their communion (of persons)? Moreover, was this communion limited to the gathered community of "fighting" believers, or did it include those "victorious," that is the departed, who went to be with the Lord?

Although some Catholic theologians favor the latter interpretation (the mystical communion of the living saints with the dead martyrs), others have disapproved of it, arguing that this cannot be the cause of its addition to the Creed. Badcock, among others, is critical of linking the phrase to the doctrine of the saints, because the purpose of the Creed is to emphasize the unalterable truths which are a necessary condition of salvation and, therefore, are unchanged ever since Pentecost (Badcock 1938, 246-47). It has been convincingly been argued that primitive Christianity knew nothing of "special" saints, as all Christians were considered holy (Benko 1964, 71) and that the communion of saints could not mean the fellowship between living and dead Christians, since at Pentecost there were no dead Christians (Badcock 1938, 246-47).

Before turning to the core of our paper, the Pentecostal understanding of the communion of the saints, in light of the Pentecostal-Roman Catholic Dialogue,

1 For more bibliography on the historical development of the doctrine, especially from the traditional/sacramental perspective, see Jaroslav Pelikan. 2005. Credo: Historical and Theological Guide to Creeds and Confessions of Faith in the Christian Tradition. New Haven: Yale University Press; Stephen Benko. 1964. The Meaning of Sanctorum Communio. London: SCM Press; J. N. D. Kelly. 1972. Early Christian Creeds. New York: Longman; Susan Wood. 2004. "The Holy Catholic Church, the Communion of Saints." In: Roger Van Harn ed. Exploring and Proclaiming the Apostles' Creed, pp. 219-232. Grand Rapids: Eerdmans; Berard Marthaler. 2007. The Creed: The Apostolic Faith in Contemporary Theology. New London: Twenty-Third Publications; Nicholas Ayo. 1990. The Creed as Symbol. Notre Dame: University of Notre Dame Press. 
two questions beg to be answered: 1) Why was this later addition to the Creed introduced? and 2) Why would it be useful for Evangelicals and Pentecostals to dwell on its understanding?

To answer the first question, it must be said that while scholarship has not yet been able to pinpoint the exact cause of "upgrading" the Creed, it is generally agreed that the aim was to proclaim and defend the truth in the face of heretical opposition, as well as to articulate the minimum and unalterable dogmatic requirements after the Church has fully made up its mind. Hans Küng, for example, believed it was introduced to reinforce the communio fidelium, which is the composite picture of the Church as a community of believers (Küng 1993, 141). The Early Church sought not to promote a form of individualistic or isolationist piety in its worship. On the contrary, as Tillard has argued, the first Christian communities exhibited a real, though fragile, fellowship on the common faith that they were united and sanctified in Christ, as one body, by the Holy Spirit (Tillard 2001, 33).

Another reason for the addition, upon which the answer to the second question depends, is a paradigm change in how Christians understood their spirituality and the meaning it brings to life. In keeping with the teachings of Jesus, who himself had initiated a theological and social paradigm change by attending to both the spiritual and social needs of His followers (see Mt. 4-5), the fourth century, after the Council of Nicaea, marked a decisive turning point in the life of the Church, as it realized the need to become socially involved and to be relevant. Since it was not difficult to figure out that Emperor Constantine's convocation of the Council had been motivated by his deeply embedded belief that religion had a social function, the Church of 380-450 AD was forced to self-reflect on its place in society. As Philip Rousseau notes, by that time the Church had reached a level of theological sophistication where it was capable of debating in new terms the relationship between religion and public life (Rousseau 2002, 237).

This last idea allows for a connection to our answer to the second question mentioned above: why is it useful to search for a Pentecostal understanding of communio sanctorum? There are many possible "gains," but I will mention only three, which, in my opinion, are the most important. First, given the bewildering global diversity of Pentecostalism(s) and the felt general scarcity of Pentecostal ecclesiological self-reflection, it is not only useful but compulsory for Pentecostals to work on a more articulated ecclesiology, to better define their own ecclesiological identity. Second, given the important place of the doctrine of communio sanctorum in the theology of the Roman-Catholic church (and other, Protestant churches), as well as the fact that it has been proven to be an excellent commonplace for mutual understanding, it will help Pentecostals to better engage in the much-needed, broader ecumenical dialogue. Thirdly and most importantly, since it originally offered the Early Church a theological motif for thinking about its 
relation to public life, Pentecostals, who become increasingly engaged in social, political, and economical life, could use it as a theological ground for framing their public engagement.

\section{An Outline of Perspectives on Koinonia}

One of the most important documents on the Pentecostal understanding of the church as a fellowship of the saints is Perspectives on Koinonia: Report from the Third Quinquennium of the Dialogue between the Pontifical Council for Promoting Christian Unity and Some Classical Pentecostal Churches and Leaders, 19851989 (Information Service 1990/IV, 179-91). ${ }^{2}$ This international dialogue, which is likely the oldest and most ecumenically important for Pentecostals, began in 1972 and continues to this day, now in its seventh "phase."

The third phase of the dialogue, in which this paper is especially interested, focused on the theme of the church, under the broader name of koinonia. ${ }^{4}$ Under this topic, participants discussed "Koinonia and the Word of God," "The Holy Spirit and the New Testament vision on koinonia," "Koinonia and baptism," "Koinonia in church life," and "Koinonia and Communion of the saints." In the following, we will present some of the main ideas contained in this document.

In the introductory section, the editors of the Report inform that the subject of "the fellowship of the saints" emerged during the second phase of the dialogue when discussions focused on Mary, the Mother of God. The participants at the time considered that, first of all, the theme of "communion" is extremely fertile in terms of possibilities and that, moreover, this theme can arouse a growing interest in world ecumenical dialogue $(P C D 3,7)$.

2 The report was published both by Information Service 1990/IV: 179-191) and PNEUMA: The Journal of the Society for Pentecostal Studies (Final Report, in Pneuma 12/1 (1990): 85-95). From here on the abbreviation PCD3 will be used to refer to this report. Also, to make it easier for the reader to follow the references, regardless of which publication venue, when referring to PCD3 in-text citations will indicate article numbers (eg. " 3 " means article 3), instead of page numbers.

3 More details on the seven phases of the dialogue, such as the timetable, theme, participants and venues, can be found here: https://www.prounione.it/dia/pe-rc/Dia-Pe-RC-Table-of-Contentsweb.pdf (accessed 25 February 2021).

4 It is important to note that the topic of koinonia was also discussed later, in the context of evangelisation and social justice, in the fourth phase of the dialogue (1990-1997). The final document, entitled Evangelisation, Proselytism and Common Witness: The Report from the Fourth Phase of the International Dialogue between the Roman Catholic Church and Some Classical Pentecostal Churches and Leaders (1990-1997), can be accessed here: https://www.prounione. it/dia/pe-rc/Dia-Pe-RC-04_1997.pdf. To make it easier for the reader to follow the references when referring to PCD4 in-text citations will indicate article numbers (eg. " 5 " means article 5), instead of page numbers. 
For Pentecostals, koinonia is an essential aspect of church life, is linked to the work of the Church in the world and the relationship between Christians. Both Roman Catholics and Pentecostals appreciate the importance of biblical koinonia, as depicted in Acts 2:42 (ESV): "And they devoted themselves to the apostles' teaching and the fellowship [koinonia], to the breaking of bread and the prayers" $(P C D 3,10)$. Of course, one of the difficulties inherent in this interfaith dialogue was to recover the historical difference between the highly evolved ecclesiology of the Roman Catholic Church and the Pentecostal one which was, to put it optimistically, in the process of elaboration. Although they do not have a full-fledged ecclesiology, Pentecostals embrace a wide range of ecclesiastical policies and care deeply about certain ecclesiological beliefs, for example, the importance of the local assembly $(P C D 3,11)$.

It should also be noted that in Section IV, Part B, entitled "Church as Koinonia," Article 73 states that "the importance of an active response to the gifts of God in the service of koinonia requires mutuality in its many dimensions" $(P C D 3,73)$. For both Catholics and Pentecostals, koinonia in the Church is a biblical, dynamic concept that "implying a dialogical structure of both Godgivenness and human response" $(P C D 3,73)$. This concept demands reciprocity at every level of the Church, and its source is the permanent presence of the Holy Spirit $(P C D 3,73)$.

The Perspectives on Koinonia report also mentions the difficulties of some Pentecostals about their ecclesiastical institutions. These seem to be generated by the Pentecostal emphasis on the direct relationship with the Spirit. Pentecostal Christians seem to forget that the Spirit is given not only to individuals but to the whole community. Roman Catholics urged Pentecostals to see the whole community as the "temple of God," in which the Holy Spirit dwells $(P C D 3,76)$.

Special attention will be given now to Section V of the Report, entitled "Koinonia and the Communion of the Saints." This section includes articles 95 to 198 and has two parts: A) "The Church as Communio Sanctorum," and B) "Holiness, Repentance and Ministry in History." In an attempt to outline what each side understands by defining the Church as communio sanctorum, the participants stated that God calls us to fellowship with himself (communion with the Holy One), with the body and blood of Christ (communio in sanctis), as well as with the other Christians (communion of saints: communio sanctorum).

In terms of communio in sanctis, Roman Catholics consider that "participation in baptism, confirmation, and Eucharist is constitutive of the Church" (PCD3, 96), while for Pentecostals "the central element of worship is the preaching of the Word" $(P C D 3,96)$. "As persons respond to the proclamation of the Word, the Spirit gives them a new birth, which is a pre-sacramental experience, thereby making them Christians and in this sense creating the Church" $(P C D 3,96)$. 
In terms of communio sanctorum, Catholics consider that in the Nicene Creed, the phrase communio sanctorum has an eschatological meaning, referring to the fact that the saints on earth and those in heaven, sealed as the same Spirit, make up a single Body $(P C D 3,95)$. Therefore, according to the Catholic understanding, communio sanctorum means a relationship with all the saints of God, both on earth and in heaven. The members of the Church are given the koinonia with the very holiness of God. As a result, they are "a great cloud of witnesses" (Heb. 12:1) and they constitute, as Revelation 7:9 states, "a great multitude, which no man could number, from every nation, from all tribes, and peoples and tongues" $(P C D 3,99)$.

A known fact, for the Roman Catholics the practice of faith involves a distinction between latria or worship of God and the dulia or veneration of the saints who have finished their run and received the crown of life $(P C D 3,100)$. Referring to the same biblical text in Hebrews 12:1, the Pentecostals agreed that in their worship the saints on earth join the worship of the Saints in heaven, forming with them one holy, catholic, and apostolic Church $(P C D 3,101)$. In other words, Pentecostals do not direct any kind of worship (latria or dulia) to the saints, but together with the saints, only to God.

Admittedly, the notion of communio sanctorum brings together two very important themes for the Christian faith, in general, and for Pentecostalism, in particular: fellowship and holiness. From an ecclesiological point of view, it is not possible to talk about the community of saints without talking about communion, but also about sanctification. Thus, reflecting on the idea of the holiness of the church, as well as the need for repentance of the church, all participants agreed on at least three issues, namely that: 1) all the baptized are called to be "saints" and therefore, according to Scripture, this is what they called themselves in the early church $(P C D 3,102) ; 2)$ because of sin, the Church always needs repentance, being at the same time holy and in need of purification or renewal, both at the level of individuals and that of its structures (PCD3, 103); and that 3) although the requirement of the priest/pastor to live in holiness is a fundamental one, his unworthiness does not invalidate the work of the Holy Spirit $(P C D 3,104)$.

As Veli-Matti Kärkkäinen notes, Pentecostal ecclesiology, which until recently was limited to the charismatic experience and has had a certain predilection for a charismatic structure of the church, open to the flow of the Spirit, was forced, face to face with the Roman Catholic church, to reflect more on the relationship between the Holy Spirit, institution and koinonia: "As charismatic fellowship, the church is a communion of participating, empowered believers" (Kärkkäinen 2001, 100). This brings us to the third and final section of the paper. 


\section{A Pentecostal Understanding of Communio Sanctorum: Toward a Theology of the Church as a Fellowship of Persons}

The Pentecostal-Roman Catholic Dialogue in Riano, Italy, which took place between 21-26 May 1985, was heavily influenced by a position paper presented by two Pentecostal theologians from former Yugoslavia: Peter Kuzmič and Miroslav Volf. The paper was entitled Communio Sanctorum: Toward a Theology of the Church as a Fellowship of Persons and it would not be an exaggeration to see it as the first Pentecostal attempt to articulate an ecclesiological vision based on the idea of communio sanctorum. In the rest of this paper we will critically interact with Kuzmič \& Volf's ecclesiological position and then point out how it helps develop a Pentecostal theology of public life.

In their paper, Kuzmič and Volf developed the idea of a charismatic church structure based on the notion of koinonia, claiming that fellowship is the key to a correct structuring of the church: "Pentecostal soteriology and pneumatology point... unmistakably in the direction of an ecclesiology of the fellowship of persons" (Kuzmič and Volf 1985, 2, italics theirs). The authors argue that the New Testament texts such as the one in 1 Corinthians 12:13 indicate that "fellowship was a common experience of baptism into the body of Christ through the Spirit" (Kuzmič and Volf 1985, 14, italics theirs).

In an article in which he presents some ecclesiological reflections from the Pentecostal-Roman Catholic Dialogue, Kärkkäinen analyses Kuzmič \& Volf’s position paper and concludes that they "sought to develop a Pentecostal view of the Church as a charismatic fellowship, a pneumatologically constituted reality" (Kärkkäinen 2001, 114). In other words, fellowship is something that is lived, an experience of life shared with others, in the daily life of the community. Kärkkäinen points out that "the question 'Where is the Church?' cannot be answered without reference to the living presence of the Holy Spirit" (Kärkkäinen 2001, 114 ) and notices in a footnote that Kuzmič \& Volf cite from Lesslie Newbigin's The Household of God, which compares Protestant, Roman Catholic and Pentecostal views on the church (Kärkkäinen 2001, 114).

According to Kuzmič \& Volf's paper, there are three basic models for structuring the church. The first, specific to classical Protestantism, is that of the "lecture room," where the emphasis is on the pulpit and the preaching of the Bible. The second, which characterizes the Roman Catholic Church, is the "theatre setting," where the emphasis is on the dramatic elements of worship. The third model is that of "Pentecostal fellowship," where the emphasis is on the visible gathering of the community for mutual edification in faith (Kuzmič and Volf 1985, 14-6). Without intending to exclude elements related to the preaching of the Word or the performance of acts of worship, Kuzmič \& Volf suggest that in the New Testa- 
ment the fundamental feature of worship is the fellowship of believers (Kuzmič and Volf 1985,15$).{ }^{5}$

Quoting Newbigin's words, Kuzmič \& Volf state that "a real congregational life, where each member has the opportunity to contribute to the life of the whole body through gifts which the Holy Spirit endows him, is as much part of the esse of the church as are ministry and sacraments" (Kuzmič and Volf 1985, 16). In other words, the dynamics of fellowship can be seen concretely in the use of the charisms of the Spirit by each believer, for the benefit or the edification of the community. The conclusion of the paper presented by Kuzmič \& Volf at the ecumenical talks in Riano is worth quoting in full:

It is clear: no social body can permanently exist without structures. The church is no exception. In the case of the Church, however, it is of fundamental importance that the structures it develops be compatible with the freedom and sovereignty of the Spirit in its own ranks. The New Testament ecclesiology suggests that pneumatocracy cannot be accomplished through the juridically structured hierarchy. Though it may seem paradoxical, if the Church is truly to be ruled from above, its structures must arise from below. The reason is simple: since all members have the Spirit, no one of them can monopolize his leading. Since the Spirit's leading is a privilege of all members, the structures of a charismatic fellowship have to arise through the interaction of all its members. Sociologically speaking, they have to be formed according to the laws of group formation. This means that special care has to be given to see that the structures born from below continually remain an outgrowth of the concrete life of the community. Otherwise they develop a tendency to become independent and hinder life instead of helping it (Kuzmič and Volf 1985, 23).

Three things can be seen about the ecclesiological vision proposed by Kuzmič $\&$ Volf, a vision that was also felt in the way in which the Pentecostal perspective on koinonia was portrayed in The Final Report of the Pentecostal-Catholic Dialogue. First, three features are constantly emphasized which, in the opinion of the authors, define the Pentecostal understanding of the Church: fellowship, charismatic fellowship, and charismatic structured fellowship (Kuzmič and Volf 1985, 23). This triad emphasizes that Pentecostals tend to see the communion of the saints from a perspective that is not ecclesiastical (the essence of fellowship is not in the presence of hierarchical church structures) or sacramental (the essence

5 In a very appreciated book, Miroslav Volf later developed his ideas, laying the foundations of a "participatory ecclesiology." See Miroslav Volf. 1998. After Our Likeness: The Church as the Image of the Trinity. Grand Rapids: Eerdmans. In his book Volf sketches some of the main features of participatory ecclesiology, drawing inspiration from the first Baptist theologian, John Smyth, and engaging in a critical dialogue with Roman Catholic Ecclesiology, represented by Cardinal Joseph Ratzinger, and with the Orthodox ecclesiology, represented by Metropolitan Ioannis Zizioulas. 
of fellowship is not in the presence and practice of the sacraments), but pneumatological: the presence of the Holy Spirit, through his charisms, manifested in all believers, towards the mutual edification of the saints.

Secondly, Kuzmič \& Volf do not forget to underline an eschatological feature of the Church: "As a charismatically structured fellowship, the Church is a beacon of hope in the midst of the old broken and divided world" (Kuzmič and Volf 1985, 23-4). While the aforementioned triad is intended to define the fellowship of the saints, this eschatological emphasis is, in our view, intended to point out the Pentecostal perception of the holiness of the fellowship; in other words, to specify the purpose of the Church in the world, as a community of holiness. This suggests that by being holy - separated from the world - members of the charismatic fellowship not only pursue the good of their community by using the charisms for mutual edification but also, by their presence and sanctified living amid the world, contribute to the common good and keep alive the hope of sanctifying the entire Creation. The following aspect should not be overlooked either: the idea of community/communion has had great importance for the Pentecostal movement, since its inception, because it provides adherents with a haven from religious, cultural, and political anomalies and abuses.

Thirdly, Kuzmič \& Volf make the connection between the manifestation of the charisms of the Holy Spirit in the fellowship and the Church's public existence in the world: "As fellowship should be the unalienable modus of the Church's existence, so the charismata should be the permanent feature of its life" (Kuzmič and Volf 1985, 16). There is, therefore, a direct connection between the charismatic, sanctifying, and communion-forming presence of the Holy Spirit and how the charismatic fellowship of the saints exists in the world. These features, coupled with the idea of the charismatic fellowship of people, are of particular relevance to the existence of the Pentecostal church in the world and, implicitly, to its relation to public life.

It is important now that we critically assess the Pentecostal perspective which results from the Perspectives on koinonia report, keeping in mind the ideas presented by Peter Kuzmič \& Miroslav Volf in their paper. Here are three questions of particular interest for our paper: 1) What are the reasons why Pentecostals were quick to embrace the somewhat ecumenical notion of koinonia as a lens for the way they see the Church? 2) What are the differences between the Pentecostal understanding of the communion of saints and the Roman Catholic one? and 3) What contribution does such a vision of the communio sanctorum make to the shaping of a Pentecostal theology of public life?

The answer to the first question is probably threefold. Thus, a first reason why the theme of koinonia caught on to Pentecostal theologians is its biblical fidelity, that is, the strong anchoring of this theme in the text of Holy Scripture (Tillard 1992, 2-20). Although his summary has a less common sacramental echo for 
Pentecostals, Kilian McDonnell, co-chair of the Dialogue at the time, summarises well the biblical perspective of the Acts of the Apostles, the Pentecostals' favorite book: "So, if one is true to the dynamics of Acts, one would add immediately after the imparting of the Spirit, koinonia/communion, i.e., community formation together with its Eucharistic expression: 'the language of Luke is communion language" (McDonnell 1988, 674). It can be said, therefore, that in the most elementary sense, koinonia denotes communion, community, participation, but also communion on a spiritual, social, and material level. From a biblical perspective, koinonia also encompasses both the Trinitarian and the pneumatological dimensions, as can be seen in the "apostolic blessing" (2 Cor. 13:14).

The second reason why Pentecostals embraced the vision of koinonia is perhaps that it strongly resonates with the way the Pentecostal movement values "fellowship" rather than the "institution" or "hierarchy" of the church. In Pentecostal teaching, koinonia is understood as an essential aspect of church life, is related to the Church's service to the world and the relationship between Christians" $(P C D 3,10)$. This is noted by the Pentecostal theologian Howard M. Ervin, who writes that "Pentecostal emphasis on new birth and the baptism of the Spirit take seriously a koinonia personal Son and the Holy Spirit." To this, Ervin adds a flattering insight, "It may hardly be gainsaid, that the Pentecostal revivals of the present century have taken the koinonia of/with the Holy Spirit out of the cloistered mystical tradition of the Church and made it the common experience of the whole people of God" (Ervin 1987, 8-9).

A third reason for the Pentecostal acceptance of koinonia-based ecclesiology is the way Pentecostal Christians understand the connection between worship and church life. For Pentecostals, the dynamics of fellowship are expressed through the manifestation of the charisms of the Holy Spirit. Daniel Albrecht $(1999,22)$ is right in arguing that "The Pentecostal service lies at the heart of the Pentecostal/Charismatic (Pent/Char) spirituality and with its attending rites and practices constitutes the most central ritual of Pentecostalism." Consequently, the liturgical experience (worship), marked by the fervent desire to "meet the Lord," is the core of Pentecostal church life. Even when the spiritual manifestations of speaking in other languages, prophecy, or healing are occasionally lacking, there is a real openness and waiting for tangible signs of God's presence in the fellowship of the saints.

The second question raised above, regarding the confessional differences in understanding the koinonia, is competently answered by Veli-Matti Kärkkäinen, in his book, Spiritus uni vult spirat. Although the fragment is quite lengthy, it is worth quoting in its entirety. The main differences, therefore

...had to do with four basic issues, the first being the most substantial: sacraments, local vs. universal church relationship (including relationship between local churches), charismatic vs. hierarchical structure of the church, 
and oneness of the church. The basic difference in the view of sacraments had to do with the Catholic claim that sacraments (baptism, Eucharist) are constitutive of the church. The Pentecostal side opposed this claim. For Pentecostals, preaching of the word and conscious faith response of the individuals are constitutive of the church. The other divergence related to the question of the priority of and relationship between the local church and universal church. Quite naturally, Catholics place more emphasis on the universal, while for Pentecostals the local church is the most important, almost to the exclusion of the other. However, Catholic theology, after Vatican II has come to appreciate more and more the role of the local church, although a definitive standpoint is still lacking as to their precise relationship. When it comes to charismatic vs. hierarchical structure of the church, Catholics emphasize the role of hierarchy, church authority, and structures, and see them as 'God given' which in themselves express koinonia. Pentecostals opt for greater 'freedom' of the Spirit and see structures as subordinate to, although important in guaranteeing order. The difficult question of Christian unity was also discussed during the third quinquennium in relation to koinonia. The question of the oneness of the church still remains a substantial point of contention. For Catholics, there is only one visible church of Christ. All divisions in the church are regarded as deviation from this basic unity. For Pentecostals, the existence of denominations is for the most part a legitimate development. Pentecostals think primarily in terms of spiritual, i.e., invisible unity (only). They have several misgivings about the structural/visible unity, e.g., the compromise of doctrine, the demise of evangelism, etc. (Kärkkäinen 1998, 109-10).

We arrive now to the third question which concerns us. It is, perhaps, the most important: What are the contributions that this ecclesiological vision makes to the shaping of a Pentecostal theology of public life? It is quite clear, we hope, from what has been presented so far that the development of an ecclesiology based on the notion of koinonia demonstrates a huge potential for the Pentecostal movement.

In a seminal article published in PentecoStudies, Kärkkäinen points out five "neglected or underdeveloped traits" in the ecclesiology of other churches, to which Pentecostal ecclesiology may be of help: "the dynamic nature of koinonia," "koinonia as the call to holiness," "mission and social justice in koinoniaecclesiology," "charisms and koinonia," and "koinonia as an eschatological reality" (Kärkkäinen 2007, 8). Although all these features are important, we will focus on only two of them, which have special relevance for the argument of our thesis: koinonia as a call to holiness and as social justice.

In keeping with the dynamic nature of the concept, the Pentecostal view of the Church as a charismatic fellowship of individuals is also a call to holiness (Kärkkäinen 2007, 8). The renowned Pentecostal theologian Amos Yong rhetorically asks, "What, then, might Pentecostals possess to contribute to the broader ecclesial understanding of the church as holy?" and then offers an answer, "Per- 
haps the pentecostal gift to the church ecumenical is a pneumatologically robust notion of sanctifying transformation" (Yong 2005, 140). This idea is extremely important because it emphasizes the importance of the social dimension of holiness, that is, the relationships within the Church as communio sanctorum, but also between the Church and the world - a dimension that has always been at the forefront of Pentecostal spirituality since the beginning of the Movement.

Kärkkäinen also points out that Pentecostals are often critical of what they perceive as a "complacency" of older churches toward members who appear to be living in sin and yet continue to be accepted as members of the church (Kärkkäinen 2007, 8). For Pentecostals, this is unacceptable, because it seems to ignore the New Testament idea of koinonia. As Yong notes, the Pentecostal perspective harmonizes with Thomas Oden's statement, according to which "the decisive proof of the holiness of the Church is, ironically, the very fact that she is among sinners, redeeming, seeking, healing, and sanctifying" (Oden 1992, 319, cited in Yong 2005, 139).

Last but not least, the Pentecostal ecclesiological vision of the charismatic fellowship of persons links the notion of koinonia to the concept of social justice, which is an important contribution to the common good. The Church, as a communion of persons, empowered by the charismatic presence of the Holy Spirit in its members, is not a community that lives only for itself. In Moltmann's words, it is "open to the world" (Moltmann 1981, 89). The fact that it lives (in) koinonia, makes it possible for the Church to become "a gift and a servant sign for the world" $(P C D 4,26)$ "a prophetic sign to entire mankind (cf. John 17:21)" (PCD4, 14). Or, as stated in Article 94 of $P C D 3$, "As the new people of God, the Church is called both to reflect the reality of God's eschatological kingdom in history and to announce it's coming into the world, insofar as people open their lives to the in-breaking of the Holy Spirit" (PCD3, 94). Therefore, because the Church is a sent community, inherent to her being in the world is to share the sufferings of the world and to alleviate poverty, injustice, and other social evils. Perhaps one of the most appropriate descriptions of how Pentecostals apply their understanding of communio sanctorum to community life is found in the PCD4 Final Report. We conclude this final of the paper with this important quotation:

In the life of the community, Pentecostals have found a new sense of dignity and purpose in life. Their solidarity creates affective ties, giving them a sense of equality. These communities have functioned as social alternatives that protest against the oppressive structures of the society at large. Along with some social critics, Pentecostals have discovered that effective social change often takes place at the communal and micro-structural level, not at the macro-structural level (PCD4, 43). 


\section{Conclusion}

In the first section of the paper, a short historical and theological survey has been presented, leading to the conclusion that scholarly opinions are divided on the meaning of the creedal phrase communio sanctorum, making it highly debatable, but not on its importance as a statement of faith. Naturally, dogmatic nuances are generated by the way different Christian traditions interpret each of the terms (communion/fellowship, holiness) in the phrase, Catholic theologians leaning towards a more mystical understanding, while Evangelical/Pentecostal theologians favor a more socially-oriented one. However, one of the reasons communio sanctorum was introduced in the Apostolic Symbol is because it reflects a consensual paradigm change in how Christians understood their spirituality and the meaning it brings to (public) life. We have argued that there is a need for continuous and serious theological reflection on today's meaning and implications of the communion of the saints, as this allows not only for a clearer self-understanding of ecclesiological identity but also for the shaping of an ecclesiologically-customized theology of engagement in public life.

The second section of the paper outlined the most important Roman Catholic and Pentecostal perspectives on koinonia, as presented in the Final Report from the Third Quinquennium of the Dialogue, 1985-1989. This has hopefully helped to identify the main convergent and divergent ideas of both sides involved in the dialogue, pointing out the need for a more robust Pentecostal reflection of the relationship between the Holy Spirit, the institution of the Church, and koinonia, thus setting the stage for a better understanding of the Pentecostal position paper.

The third and final section of the paper presented and critically engaged with Kuzmič \& Volf's position paper read at the Dialogue in Riano, which is considered the first academic attempt to sketch a Pentecostal understanding of the communio sanctorum. Contrasting the Pentecostal "model" of church structure ('fellowship') with the Roman-Catholic ('theatre setting') and Protestant ('lecture room') ones, Kuzmič \& Volf argued that Pentecostal soteriology and pneumatology point toward an ecclesiology of the fellowship of believers. This is a charismatic communion of sanctified, empowered, and participating persons, where "charismatic" refers to the dynamic and concrete use of the charismata by each believer, for the edification of the entire community. Besides this important conclusion, we have noted that Kuzmič \& Volf emphasize the eschatological dimension of the Church's existence in the world, which generates practical, day-to-day, society-transforming implications.

To conclude, it is obvious that a Pentecostal ecclesiological vision that understands communio sanctorum as a charismatic fellowship of believers is pregnant with the potential of generating a robust, yet socially practical theological matrix for a Pentecostal theology of public life. One can only concur with Amos Yong's 
aforementioned commanding, yet bold statement, that "the Pentecostal gift to the church ecumenical is a pneumatologically robust notion of sanctifying transformation" (Yong 2005, 140).

\section{References}

*** "Evangelisation, Proselytism and Common Witness: The Report from the Fourth Phase of the International Dialogue between the Roman Catholic Church and Some Classical Pentecostal Churches and Leaders (19901997)." https://www.prounione.it/dia/pe-rc/Dia-Pe-RC-04_1997.pdf (accessed February 26, 2021).

*** "Perspectives on Koinonia. Report from the Third Quinquennium of the Dialogue between the Pontifical Council for Promoting Christian Unity and Some Classical Pentecostal Churches and Leaders, 1985-1989". Information Service 75 (1990/IV), 179-191. http://www.prounione.urbe.it/ dia-int / pe-rc / doc/e_pe-rc_pent03f.html (accessed February 14, 2021).

Albrecht, E. Daniel. 1999. Rites in the Spirit: A Ritual Approach to Pentecostal/ Charismatic Spirituality. Sheffield: Sheffield Academic Press.

Ayo, Nicholas. 1990. The Creed as Symbol. Notre Dame, Indiana: University of Notre Dame Press.

Barclay, William. 1967. The Plain Man Looks at the Apostles' Creed. Glasgow: Fontana Books.

Badcock, F. J. 1938. The History of the Creeds. New York: MacMillan.

Brown, Peter. 1981. The Cult of the Saints: Its Rise and Function in Latin Christianity. Chicago: University Press.

Benko, Stephen. 1964. The Meaning of Sanctorum Communio. London: SCM Press.

Burn, A. E. 1964. Niceta of Remesiana, His Life and Works. Cambridge: University Press.

Carson, Thomas, and Cerrito, Joann (eds.). 2003. New Catholic Encyclopaedia, vol. 4, 2nd edition. USA: Gale.

DeLorenzo, Leonard J. 2017. Work of Love: A Theological Reconstruction of the Communion of Saints. Notre Dame: University of Notre Dame Press.

Ervin, Howard. 1987. Koinonia, Church, and Sacraments: A Pentecostal Response, unpublished paper, presented at the International PentecostalCatholic Dialogue in Venice, 1-8 August 1987. https://digitalshowcase.oru. edu/cgi/viewcontent.cgi? referer=https://www.google.com/\&httpsredir=1\& article $=1005 \&$ context $=$ ervin_bio (accessed November 24, 2020). 
Heurtley, Charles A. 1858. Harmonia Symbolica: A Collection of Creeds Belonging to the Ancient Western Church. Oxford: University Press.

Kuzmič, Peter, and Volf, Miroslav. 1985. "Communio Sanctorum: Toward a Theology of the Church as a Fellowship of Persons". Unpublished Pentecostal position paper presented at the International PentecostalRoman Catholic Dialogue, Riano, Italy, May 21-26, 1985.

Imbelli, Robert P. 1998. "Friends of God and Prophets: A Feminist Theological Reading of the Communion of Saints". Commonwealth 125 (8): 24-26.

Johnson, Elizabeth A. 1998. Friends of God and Prophets: A Feminist Theological Reading of the Communion of Saints. New York: Continuum.

Kärkkäinen, Veli-Matti. 1998. Spiritus ubi vult spirat: Pneumatology in Roman Catholic-Pentecostal Dialogue (1972-1989). Schriften dar Luther-AgricolăGesellschaft 42. Helsinki: Luther-Agricola Society.

Kärkkäinen, Veli-Matti. 2001. "Church as Charismatic Fellowship:

Ecclesiological Reflections from the Pentecostal-Roman Catholic

Dialogue". Journal of Pentecostal Theology 09: 100-121.

Kärkkäinen, Veli-Matti. 2007. "The Church as a Fellowship of Persons: An Emerging Pentecostal Ecclesiology of Koinonia." PentecoStudies 6 (1): 1-15.

Kelly, J. N. D. 1972. Early Christian Creeds. Essex: Longman House.

Küng, Hans. 1993. Credo: The Apostles' Creed Explained for Today. London: SCM Press.

Marthaler, Berard. 2007. The Creed: The Apostolic Faith in Contemporary Theology, 3rd revised edition. New London: Twenty-Third Publications.

McDonnell, Kilian. 1998. "Communion Ecclesiology and Baptism in the Spirit: Tertullian and the Early Church." Theological Studies 49: 671-693.

Moltmann, Jürgen. 1981. The Trinity and the Kingdom: The Doctrine of God. Translated by M. Kohl. San Francisco: Harper \& Row.

Oden, Thomas. 1992. Systematic Theology, vol. 3, Life in the Spirit. SanFrancisco: HarperSanFrancisco.

Pelikan, Jaroslav. 2005. Credo: Historical and Theological Guide to Creeds and Confessions of Faith in the Christian Tradition. New Haven: Yale University Press.

Rousseau, Philip. 2002. The Early Christian Centuries. London: Longman.

Tillard, Jean-Marie-Roger. 1992. Church of Churches: The Ecclesiology of Communion. Collegeville: Liturgical Press.

Tilllard, J. M. R. 2001. Flesh of the Church, Flesh of Christ, at the Source of the Ecclesiology of Communion. Collegeville: Liturgical Press. 
Volf, Miroslav. 1998. After Our Likeness: The Church as the Image of the Trinity. Grand Rapids: Eerdmans.

Wood, Susan. 2004. "Sanctam Ecclesiam Catholicam, Sanctorum

Communionem." In: Roger Van Harn, ed. Exploring and Proclaiming the Apostles' Creed, 219-232. Grand Rapids: Eerdmans.

Yong, Amos. 2005. The Spirit Poured Out on All Flesh: Pentecostalism and the Possibility of Global Theology. Grand Rapids: Baker Academic.

Ciprian Gheorghe-Luca

Promišljanja o dokumentu „Communio sanctorum: Toward a Theology of the Church as a Fellowship of Persons" Petera Kuzmiča i Miroslava Volfa, u kontekstu dijaloga između Pentekostalne i Katoličke Crkve

\author{
Sažetak
}

Svrha je ovoga članka promišljanje o pentekostalnom načinu razumijevanja zajedništva svetih, slijedom kritičkog bavljenja eklezijalnom vizijom dvojice svjetskih pentekostalnih teologa iz postkomunističkih zemalja: Petra Kuzmiča i Miroslava Volfa. Članak se sastoji od tri dijela: u prvom je dijelu predstavljen kratak povijesni i teološki pregled doktrine communio sanctorum, sa svrhom uspostavljanja primjerenog konteksta za daljnja razmatranja te jasnog ukazivanja na korisnost razmišljanja o ovoj važnoj ekleziološkoj temi. Drugi dio donosi pregled dokumenta „Perspektive Koinoniae“ (Završno izvješće s Treće petogodišnjice pentekostalno-rimokatoličkog dijaloga), usredotočujući se na prvi krug razgovora (Riano, Italija, 1985.) koji su se odvijali na temu razumijevanja pojma communio sanctorum. U trećem dijelu, autor predstavlja i komentira dokument Kuzmiča i Volfa „Teologija Crkve kao zajedništva osoba“, koji predstavlja jedan od najranijih pokušaja artikuliranja pentekostalne ekleziologije temeljem poimanja communio sanctorum. Autor na kraju pokazuje kako ova ekleziološka vizija pomaže pri oblikovanju pentekostalne teologije javnoga društvenog života. 